\title{
Contents Analysis of Activities on Group Art Therapy Programs to Improve the Self-Esteem of Elementary School Students
}

\section{초등학생의 자아존중감 향상을 위한 집단미술치료 프로그램 활동 내용 분석}

Mi-Hun Kim ${ }^{1}$, Hyundong Son ${ }^{2}$

김미헌 1 , 손현동 2

${ }^{1}$ Teacher, Gwangju Hwajungnam Elementary School, Korea, hunartmh@naver.com

${ }^{2}$ Professor, Department of Education, Gwangju National University of Education, Korea, chamcoun@gnue.ac.kr

Corresponding author: Hyundong Son

\begin{abstract}
The purpose of this study was to analyze the activities of group art therapy programs to improve the self-esteem of elementary school students and to present the theoretical basis and basic data for future program development. The subject of analysis was 65 papers selected according to the selection criteria among degree thesis published in Korea from 2001 to August 2019. Through reviewing the literature, a tool for analyzing the contents of activities was developed. The tool is composed of 5 categories and 10 factors, with 54 activities in total. Each activity of the program was analyzed by frequency. The results are as follows: First, the elements of programs are 'relationship forming', 'selfacceptance', 'acceptance of others', 'sense of competence and accomplishment', and 'closing'. Of these, activities related to 'self-acceptance' were used the most. Second, as the results of usage frequency analysis, each program showed that introducing programs, exploring materials, advertising myself, expressing negative emotions, drawing a picture of a family, replicating a peer's body part, drawing a cooperative picture, expressing my future, art exhibition, and giving-oneself-a-reward activity by subcategory were most commonly used. The results of this study are intended to contribute in raising the usefulness and efficiency of new programs in the future.
\end{abstract}

Keywords: Elementary School Students, Self-esteem, Group Art Therapy Program, Contents Analysis

요약: 이 연구의 목적은 초등학생의 자아존중감 향상을 위한 집단미술치료 프로그램의 활동을 분석하여 추후 프로그램 개발 시 이론적 근거와 기초자료로 사용될 수 있도록 하는 것이었다. 분석 대상 논문은 2001년부터 2019년 8월까지 국내에 발표된 학위논문 중 선정 기준에 따라 선별된 65 편이었다. 선행연구 분석을 통해 활동 내용 분석을 위한 분석 도구를 개발하였는데, 5 가지 구성요소와 10 개의 하위 범주를 가지고 있었고 총 활동 명 수는 54 개였다. 분석 논문 내 프로그램의 각 활동을 빈도별로 분석한 결과는 다음과 같다. 첫째, '관계 형성', ‘자기수용', ‘타인 수용', ‘유능감 및 성취감’, ‘마무리’의 구성 요소 중에서 ‘자기수용’과 관련된 활동이

*This study is a revised and supplemented thesis for the first author's Master's degree (Gwangju National University of Education, 2020).

Received: March 16, 2021; 1st Review Result: May 01, 2021; 2nd Review Result: June 19, 2021

Accepted: July 31, 2021 
가장 많았다. 둘째, 프로그램 활동 빈도를 분석한 결과, 각 하위 범주별로 프로그램 소개하기, 재료 탐색하기, 나를 광고하기, 부정적 감정 표현하기, 가족 모습 그리기, 친구 신체 본뜨기, 협동화 그리기, 나의 미래 모습 표현하기, 작품전시회, 나에게 주는 상장 활동 등이 주로 많이 활용되고 있는 것으로 나타났다. 이 연구결과는 앞으로 프로그램 개발 시 유용성과 효율성을 높이는데 기여할 것으로 기대된다.

핵심어: 초등학생, 자아존중감, 집단미술치료 프로그램, 내용분석

\section{1. 서론}

자아존중감은 자신을 가치 있고 능력 있는 사람이라고 생각하는 종합적인 평가이다. 그 래서 자아존중감은 아동의 다양한 삶에 영향을 미친다. 특히 자아존중감이 높은 아동은 자기표현이 풍부하며 대인관계 등 사회적 상황에서 성공적이다[1]. 또한 높은 자아존중감 을 가진 아동은 책임감과 학업 충실도가 높아 학교생활에 긍정적인 것으로 밝혀졌다[2].

초등학교 시기는 아동이 자신에 대해 새롭게 지각하여 자아를 형성하고, 여러 가지 경 험을 통해 인지와 정서를 내면화하는 시기이다. 또한 부모에 대한 감정적 의존이 점차적 으로 감소해 독립적이 되며 또래 친구들과의 친밀감에 대한 옥구가 증가한다. 아동은 자 기 자신에 대한 이해와 함께 부모, 교사, 친구들과 같이 주변 사람들과의 상호작용을 통 해 자아존중감이 발달하게 되는데, 이렇게 형성된 자아존중감은 이후 전 생애에 걸친 삶 의 적응과 태도에 중요한 역할을 하게 된다[3]. 그러나 초등학교에서 아동들이 맞게 되는 다양한 갈등 상황, 교사 및 또래들과의 인간관계, 학교 부적응 등 여러 문제들은 아동들 의 자아존중감을 위협하는 요인들이 된다[4]. 특히 아동이 교사와 또래 관계에서 수용과 지지를 받지 못하고, 우울, 분노, 두려움, 불안 등의 부정적인 감정들을 계속해서 경험하 는 경우 자아존중감은 낮아지게 된다. 게다가 이 시기에 형성된 자아존중감은 이후에도 상당히 유지되는 경향이 있으므로[5] 초등학교 시기의 자아존중감 형성과 발달은 중요하 다.

그래서 지금까지 초등학생의 자아존중감 향상을 위한 프로그램들이 다양한 유형으로 개발되었다. 프로그램 특성에 따른 자아존중감 효과 크기를 비교한 논문[6]에서 미술, 음 악, 놀이와 같은 예체능 활동을 포함하는 프로그램과 포함하지 않는 프로그램으로 나누 었을 때 예능 활동 프로그램이 다른 프로그램들보다 약 3 배 정도 자아존중감의 향상에 효과가 큰 것으로 나타났다. 또한 국내 자아존중감 향상 프로그램 메타분석에 따르면 초 등학생에게 가장 높은 효과 크기를 보이는 프로그램은 심리 치료적 접근이며 그다음이 예술치료 프로그램이었다[7].

이런 결과는 아직 자신의 의견을 표현하는 데 능숙하지 못한 초등학생의 발달 단계상 언어적 표현보다는 비언어적 표현으로 거부감 없이 자신의 감정을 자연스럽게 표현할 수 있도록 예체능을 활용한 프로그램들이 효과가 있음을 보여주고 있다. 특히 미술활동은 논리적 언어 표현과는 달리 시각적 공간적 표현 방법과 다양한 매체들을 사용하여 내면 의 세계를 자유롭고 부담 없이 표현할 수 있는 활동이다. 따라서 이러한 미술을 활용한 ‘미술치료(art therapy)'는 다른 자아존중감 향상 프로그램들에 비해 아동기의 발달단계에 적합하다고 할 수 있다. 왜냐하면 미술치료 프로그램은 자기표현뿐 아니라 자신에 대한 이해, 타인에 대한 이해, 유능감과 성취감을 경험하게 할 수 있기 때문이다.

향후에는 초등학생의 상태와 요구에 맞는 자아존중감 프로그램을 개발할 필요가 있다 
[8]. 그러나 지금까지 이루어진 초등학생을 대상으로 한 자아존중감 향상 프로그램에 관 한 연구들은 프로그램의 효과 검증에 관한 것이 대부분이었다. 이들을 종합한 연구들이 있었으나[7][9] 프로그램의 효과 크기에 대한 연구와 형식적 분석이었을 뿐 프로그램 개 발 및 구성에 적용할 수 있는 각 단계별 프로그램의 활동 내용과 활용 현황에 대한 구체 적인 분석들이 없어 새로운 프로그램을 개발하고 적용하는데 어려움이 많았다.

이에 이 연구는 지금까지 발표된 국내 논문에서 초등학생의 자아존중감 향상을 위한 집단미술치료 프로그램의 형식과 각 단계별 활동 내용, 활용 현황을 분석하여 자아존중 감 향상을 위한 집단미술치료 프로그램 개발과 구성에 이론적 근거와 구체적인 활용 방 안을 제시하는 데 목적이 있다.

\section{2. 연구방법}

\section{1 연구 문제}

연구 문제는 '초등학생의 자아존중감 향상을 위한 집단미술치료 프로그램은 어떤 형식 으로 구성되어 있으며 어떤 활동 내용으로 이루어져 있는가?’이다.

\section{2 연구 대상}

이 연구의 대상은 2001년부터 2019년 8월까지 한국교육학술정보원(http://www.riss.kr)에 등재된 국내에 발표된 학위논문 65 편(박사학위논문 3 편과 석사 학위논문 62 편)이다. 분석 대상을 석·박사 학위 논문으로 한정한 것은 학술지에 실린 논문들에 비해 분석하고자 하 는 집단미술치료 활동 내용을 회기별로 구체적이고 상세히 설명되어 있기 때문이다. 그 리고 2001년 이전 논문의 경우는 검색되는 연구 수가 적고, 회기 별 각 프로그램의 내용 이 구체적으로 제시되어 있지 않아 프로그램 활동 내용을 분석하기에 적합하지 않으므로 2001년 이후로 한정하였다.

[표 1] 분석대상 논문의 발표 연도

[Table 1] Publication Year of the Paper to be Analyzed

\begin{tabular}{|c|c|c|c|c|c|c|c|c|c|}
\hline 연도 & 2002 & 2003 & 2004 & 2005 & 2006 & 2007 & 2008 & 2009 & 2010 \\
\hline$n$ & 2 & 2 & 4 & 1 & 2 & 3 & 5 & 7 & 9 \\
$(\%)$ & $(3.1)$ & $(3.1)$ & $(6.2)$ & $(1.5)$ & $(3.1)$ & $(4.6)$ & $(7.7)$ & $(10.8)$ & $(13.8)$ \\
\hline 2011 & 2012 & 2013 & 2014 & 2015 & 2016 & 2017 & 2018 & 2019 & 합계 \\
\hline$n$ & 4 & 3 & 1 & 4 & 4 & 3 & 4 & 3 & 65 \\
$(\%)$ & $(6.2)$ & $(4.6)$ & $(1.5)$ & $(6.2)$ & $(6.2)$ & $(4.6)$ & $(6.2)$ & $(4.6)$ & $(100)$ \\
\hline
\end{tabular}

1 차로 검색된 165 편의 논문 중 프로그램의 회기 별 활동 내용이 누락되었거나 온라인 으로 논문을 제공하지 않는 경우는 분석논문 대상에서 제외되었다. 그 결과 총 65 편의 논문이 최종 선정되었으며, 분석대상 논문들이 발표된 연도는 [표 1]과 같다.

\section{3 분석 절차}


내용분석법의 일반적 절차는 연구 문제의 형성, 대상 문헌자료의 모집단 규정, 문헌자 료의 표본 추출, 분석 내용의 범주 설정, 분석단위의 규정, 수량화의 체계 규정, 타당도와 신뢰도의 점검으로 진행된다[10]. 이 연구에서는 이러한 내용분석법을 프로그램 내용 분 석에 활용한 연구[11]의 절차를 따라 이론적 고찰, 연구 대상 선정, 활동 내용 분석 도구 개발, 활동 내용 분석 실시, 분석 결과의 해석, 시사점 도출의 순서로 진행하였다.

[표 2] 집단미술치료 프로그램 하위 범주 분석

[Table 2] Analysis of Subcategories of Group Art Therapy Program

\begin{tabular}{|c|c|c|c|c|c|}
\hline 단계 & $\begin{array}{l}\text { 구성 } \\
\text { 요소 }\end{array}$ & 하위 범주 & 세부 활동 명 & \multicolumn{2}{|c|}{ 활동수 } \\
\hline \multirow[t]{2}{*}{ 초기 } & \multirow{2}{*}{$\begin{array}{l}\text { 관계 } \\
\text { 형성 }\end{array}$} & $\begin{array}{l}\text { 프로그램소개 } \\
\text { 및 자기소개 }\end{array}$ & 프로그램 소개하기, 명찰 만들기, 별칭 짓기, 기타 자기소개활동 & 4 & \multirow[t]{2}{*}{7} \\
\hline & & 친밀감 형성 & 난화 그리기, 자유화 그리기, 재료탐색하기 & 3 & \\
\hline \multirow{6}{*}{ 중기 } & \multirow{2}{*}{$\begin{array}{l}\text { 자기 } \\
\text { 수용 }\end{array}$} & $\begin{array}{c}\text { 자기인식 및 } \\
\text { 이해 }\end{array}$ & $\begin{array}{l}\text { 자화상 그리기, 자소상 만들기, 가면 만들기, 나를 광고하기, 내가 } \\
\text { 좋아하는 것과 싫어하는 것, 내가 원하는 것, 나의 과거/현재/미래 } \\
\text { 표현하기, 나의 장점과 단점 찾기, 기타 자기탐색활동 }\end{array}$ & 9 & \multirow{2}{*}{16} \\
\hline & & $\begin{array}{l}\text { 자기표현 및 } \\
\text { 수용 }\end{array}$ & $\begin{array}{l}\text { 색으로 감정표현하기, 다양한 감정 표현하기, 부정적 감정 표현하 } \\
\text { 기, 나의 손 표현하기, 은유적 초상화 그리기, 나의 감정캐릭터 만 } \\
\text { 들기, 기타 자기표현활동 }\end{array}$ & 7 & \\
\hline & \multirow{2}{*}{$\begin{array}{l}\text { 타인 } \\
\text { 수용 }\end{array}$} & $\begin{array}{c}\text { 가족관계 } \\
\text { 이해 및 수용 }\end{array}$ & $\begin{array}{l}\text { 동물 가족화, 물고기 가족화, 가족 소개하기, 가족모습 그리기, 가 } \\
\text { 족에게 선물하기 }\end{array}$ & 5 & \multirow[b]{2}{*}{14} \\
\hline & & $\begin{array}{l}\text { 타인관계 } \\
\text { 이해 및 수용 }\end{array}$ & $\begin{array}{l}\text { 친구의 장점 찾기(칭찬하기), 친구에게 편지나 선물하기, 신체 본뜨 } \\
\text { 기, 다른 사람에게 선물하기, 소중한 사람 표현하기, 학교생활화 그 } \\
\text { 리기, 그림으로 대화하기, 음식 만들기, 기타 타인이해활동 }\end{array}$ & 9 & \\
\hline & \multirow{2}{*}{$\begin{array}{l}\text { 유능감 } \\
\text { 및 } \\
\text { 성취감 }\end{array}$} & $\begin{array}{l}\text { 협동 및 } \\
\text { 문제해결 }\end{array}$ & $\begin{array}{l}\text { 분할조각 그림 그리기, 협동화 그리기, 돌려 가며 그리기, 만화 이 } \\
\text { 어 그리기, 우리 마을 꾸미기, 협동하여 만들기, 역할극 하기 }\end{array}$ & 7 & \multirow{2}{*}{12} \\
\hline & & 성취감 & $\begin{array}{l}\text { 미래 모습 표현하기, 미래를 위해 계획 세우기, 미래의 나의 나무 } \\
\text { 만들기, 나의 씨앗, 기타 성취감활동 }\end{array}$ & 5 & \\
\hline \multirow{2}{*}{ 종결 } & \multirow{2}{*}{ 마무리 } & 피드백 & 친구에게 해주고 싶은 말, 작품전시회, 수료파티 & 3 & \multirow{2}{*}{5} \\
\hline & & 자기평가 & 나에게 주는 상장, 나에게 편지나 선물하기 & 2 & \\
\hline & \multicolumn{2}{|c|}{ 총 활 동명 수 } & & \multicolumn{2}{|c|}{54} \\
\hline
\end{tabular}

이 중 이 연구에서 사용된 활동 내용 분석 도구는 먼저 각 하위 범주에 따른 분석 단 위의 설정을 위해 분석 대상 논문의 $20 \%$ 정도인 15 편의 프로그램의 세부 강의안과 활동 지를 요약정리한 결과를 바탕으로 세부 활동 내용의 기준을 정하였다. 논문의 프로그램 에서 활동명이 제시되어 있지 않거나, 활동명이 불명확한 경우는 프로그램의 목표나 활 동 내용을 정확히 살펴보고 하위 범주의 목표에 따라 활동명을 재선정하였다. 이 과정을 통해 54가지로 활동명을 설정하고 명칭을 재정리하였다. 이러한 과정을 통해 만든 분석 도구는 상담심리학을 전공한 박사 3명의 검토로 타당도와 신뢰도를 높였다.

그리고 추출된 활동들을 하위 범주로 분석하였다. 이 과정에서는 우선 미술치료의 진행 단계와 관련된 연구들을 고찰한 후, 집단미술치료 프로그램의 단계를 초기, 중기, 종결의 3 단계로 설정하였다. 그리고 프로그램의 구성요소과 하위 범주 및 목표 선정은 자아존중 
감 향상 프로그램의 구성 및 개발에 관한 여러 선행연구들을 참고하였다. 그 결과 초기 단계는 '관계 형성', 중기 단계는 ‘자기수용', ‘타인 수용', ‘유능감 및 성취감’으로, 종결단 계는 '마무리'의 5 개 구성요소로 결정하였다. 각 구성요소에 따른 하위 범주를 살펴보면 관계 형성은 ‘프로그램 소개 및 자기소개', ‘친밀감 형성', 자기수용은 '자기인식 및 이해', ‘자기표현 및 수용', 타인 수용은 '가족관계 이해 및 수용', '타인관계 이해 및 수용', 유능 감 및 성취감은 '협동 및 문제해결', ‘성취감', 마무리는 ‘피드백', ‘자기평가’로 나누었다. 이런 구성요소와 하위 범주에 따라 세부 활동을 파악하기 위한 분석 도구의 하위 범주와 세부 활동명은 [표 2]와 같다.

그리고 분석 도구에 기초하여 연구 대상이 된 프로그램의 각 활동을 분류한 후, 활용 빈도를 수량화하여 빈도 분석하였다. 그리고 각 영역의 활용 빈도를 비교 분석하여 결과 와 시사점을 도출하였다.

\section{3. 연구결과}

\section{1 구성요소 및 하위 범주별 활동 빈도}

프로그램의 구성요소별로 분석한 결과 프로그램의 주요 구성요소 빈도는 자기수용(36.3\%), 타인 수용(20.8\%), 관계 형성(16.8\%), 유능감 및 성취감(18.4\%), 마무리(7.7\%) 순으로 나타났다([표 3] 참조).

[표 3] 프로그램의 구성요소 및 하위 범주별 빈도분석

[Table 3] Frequency Analysis of Program Components and Subcategories

\begin{tabular}{|c|c|c|c|c|c|c|c|c|c|c|c|}
\hline $\begin{array}{l}\text { 구성 } \\
\text { 요소 }\end{array}$ & \multicolumn{2}{|c|}{ 관계 형성 } & \multicolumn{2}{|c|}{ 자기수용 } & \multicolumn{2}{|c|}{ 타인 수용 } & \multicolumn{2}{|c|}{$\begin{array}{c}\text { 유능감 } \\
\text { 및 성취감 }\end{array}$} & \multicolumn{2}{|c|}{ 마무리 } & \multirow{2}{*}{$\begin{array}{l}\text { 합계 } \\
\text { 합계 }\end{array}$} \\
\hline 범주 명 & $\begin{array}{l}\text { 프로그램 } \\
\text { 소개 및 } \\
\text { 자기소개 }\end{array}$ & $\begin{array}{c}\text { 친밀감 } \\
\text { 형성 }\end{array}$ & $\begin{array}{c}\text { 자기인식 } \\
\text { 및 이해 }\end{array}$ & \begin{tabular}{|c|} 
자기표현 \\
및 수용
\end{tabular} & $\begin{array}{c}\text { 가족관계 } \\
\text { 이해 및 } \\
\text { 수용 }\end{array}$ & \begin{tabular}{|c} 
타인 관계 \\
이해 및 \\
수용
\end{tabular} & $\begin{array}{c}\text { 협동 및 } \\
\text { 문제 } \\
\text { 해결 }\end{array}$ & 성취감 & 피드백 & $\begin{array}{l}\text { 자기 } \\
\text { 평가 }\end{array}$ & \\
\hline $\begin{array}{c}n \\
(\%)\end{array}$ & $\begin{array}{c}104 \\
(10.3)\end{array}$ & $\begin{array}{c}65 \\
(6.4)\end{array}$ & $\begin{array}{c}192 \\
(19.0)\end{array}$ & $\begin{array}{c}174 \\
(17.3)\end{array}$ & $\begin{array}{c}55 \\
(5.5)\end{array}$ & $\begin{array}{c}155 \\
(15.4)\end{array}$ & $\begin{array}{c}85 \\
(8.4)\end{array}$ & $\begin{array}{c}100 \\
(9.9)\end{array}$ & $\begin{array}{c}47 \\
(4.7)\end{array}$ & $\begin{array}{c}31 \\
(3.1)\end{array}$ & $\begin{array}{l}1,008 \\
(100)\end{array}$ \\
\hline $\begin{array}{l}\text { 합계 } \\
(\%)\end{array}$ & \multicolumn{2}{|c|}{$\begin{array}{c}169 \\
(16.8)\end{array}$} & \multicolumn{2}{|c|}{$\begin{array}{c}366 \\
(36.3)\end{array}$} & \multicolumn{2}{|c|}{$\begin{array}{c}210 \\
(20.8)\end{array}$} & \multicolumn{2}{|c|}{$\begin{array}{c}185 \\
(18.4)\end{array}$} & \multicolumn{2}{|c|}{$\begin{array}{c}78 \\
(7.7)\end{array}$} & $\begin{array}{l}1,008 \\
(100)\end{array}$ \\
\hline
\end{tabular}

자기수용 영역에서는 자기인식 및 이해(19.0\%)의 활동 수가 가장 많았고, 자기표현 및 수용 $(17.3 \%)$, 타인 관계 이해 및 수용 $(15.4 \%)$, 프로그램 소개 및 자기소개 $(10.3 \%)$, 성취감 $(9.90 \%)$, 협동 및 문제 해결 $(8.4 \%)$, 친밀감 형성 $(6.4 \%)$, 피드백 $(4.7 \%)$, 자기평가 $(3.1 \%)$ 순으로 나타났다.

\section{2 하위 범주의 세부 활동 빈도 분석}

\subsection{1 관계 형성}

관계 형성에서는 프로그램 소개 및 자기소개(61.5\%)가 친밀감 형성(38.5\%) 관련 활동보다 많은 것으로 나타났다. 각 하위 범주의 세부 활동을 살펴보면 프로그램 소개 및 자기소개에 대한 세부 활동은 프로그램 소개하기(46.2\%)가 가장 많았고, 별칭 
짓기(24.0\%), 이름 꾸미기(15.4\%), 기타 자기소개 활동(14.4\%) 순이었다([표 4] 참조). 그리고 친밀감 형성에 대한 세부 활동은 자유화 그리기 $(36.9 \%)$ 가 가장 많았고, 재료 탐색하기(33.8\%), 난화 그리기(29.2\%) 순으로 나타났다.

[표 4] 관계 형성의 하위 범주의 세부 활동 빈도분석

[Table 4] Frequency Analysis of Activities by Subcategory of Relationship Formation

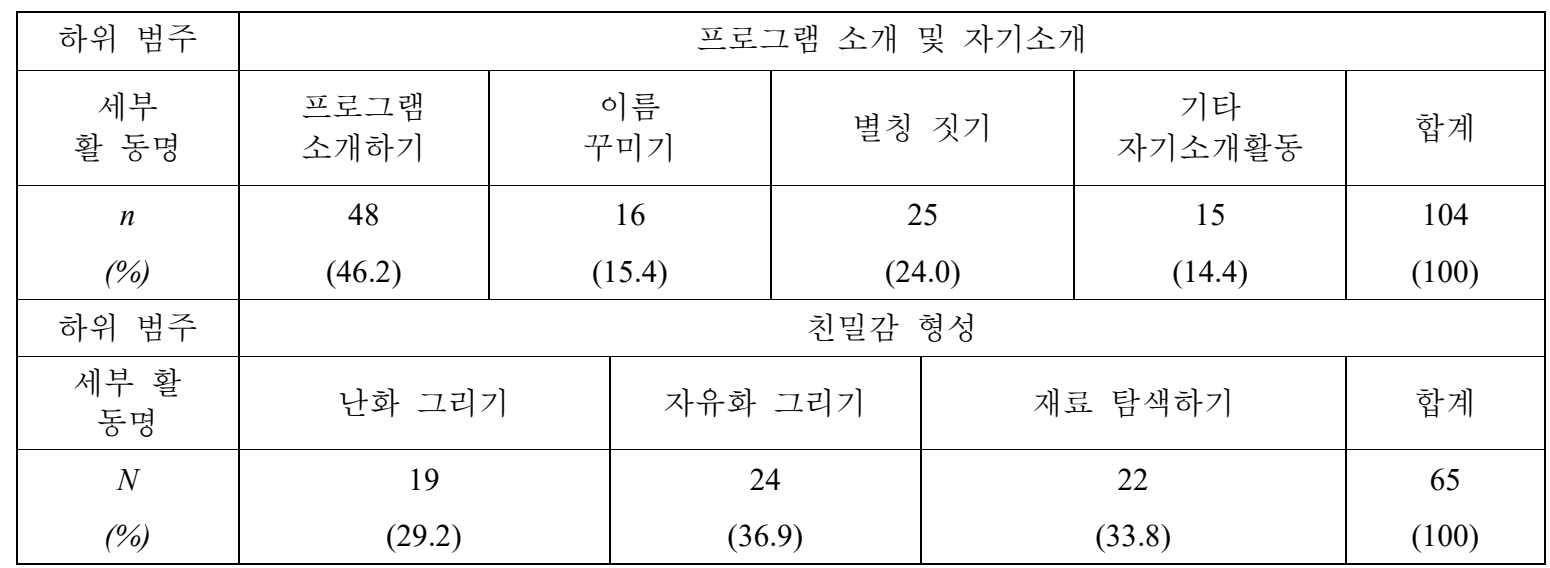

\subsection{2 자기수용}

자기수용 단계에서는 자기인식 및 이해(52.5\%)가 자기표현 및 수용(47.5\%)에 비해 많은 것으로 나타났다. 각 하위 범주의 세부 활동에 대한 빈도 중 자기인식 및 이해에서는 나의 장점과 단점 찾기(16.1\%), 가면 만들기(12.5\%), 나를 광고하기 $(12.0 \%)$ 활동이 가장 많았다([표 5] 참조). 자기표현 및 수용에서는 부정적 감정 표현하기(26.4\%)가 가장 많았으며, 다양한 감정 표현하기(23.6\%), 나의 손 본뜨기 $(7.5 \%)$, 색으로 감정 표현하기(5.7\%) 순으로 나타났다.

[표 5] 자기수용의 하위 범주의 세부 활동 빈도분석

[Table 5] Frequency Analysis of Activities by Subcategory of Self-acceptance

\begin{tabular}{|c|c|c|c|c|c|c|c|c|c|c|c|c|c|c|}
\hline $\begin{array}{l}\text { 하위 } \\
\text { 범주 }\end{array}$ & \multicolumn{14}{|c|}{ 자기인식 및 이해 } \\
\hline $\begin{array}{c}\text { 세부 } \\
\text { 활 동명 }\end{array}$ & $\begin{array}{l}\text { 자화상 } \\
\text { 그리기 }\end{array}$ & \multicolumn{2}{|c|}{$\begin{array}{l}\text { 자소상 } \\
\text { 만들기 }\end{array}$} & \begin{tabular}{|c|} 
가면 \\
만들기
\end{tabular} & $\begin{array}{l}\text { 나를 } \\
\text { 광고 } \\
\text { 하기 }\end{array}$ & \multicolumn{2}{|c|}{$\begin{array}{c}\text { 좋아하는 } \\
\text { 것과 싫어 } \\
\text { 하는 것 }\end{array}$} & \multicolumn{2}{|c|}{$\begin{array}{c}\text { 내가 } \\
\text { 원하는 } \\
\text { 것 }\end{array}$} & \multicolumn{2}{|c|}{$\begin{array}{l}\text { 나의 과거/ } \\
\text { 현재/미래 } \\
\text { 표현하기 }\end{array}$} & $\begin{array}{c}\text { 나의 } \\
\text { 장점과 } \\
\text { 단점 찾기 }\end{array}$ & $\begin{array}{l}\text { 기타 자기 } \\
\text { 탐색 활동 }\end{array}$ & 합계 \\
\hline $\begin{array}{c}n \\
(\%)\end{array}$ & $\begin{array}{c}19 \\
(9.9)\end{array}$ & \multicolumn{2}{|c|}{$\begin{array}{c}11 \\
(5.7) \\
\end{array}$} & $\begin{array}{c}24 \\
(12.5)\end{array}$ & $\begin{array}{c}23 \\
(12.0)\end{array}$ & \multicolumn{2}{|c|}{$\begin{array}{c}20 \\
(10.4) \\
\end{array}$} & \multicolumn{2}{|c|}{$\begin{array}{c}21 \\
(10.9) \\
\end{array}$} & \multicolumn{2}{|c|}{$\begin{array}{c}9 \\
(4.7) \\
\end{array}$} & $\begin{array}{c}31 \\
(16.1) \\
\end{array}$ & $\begin{array}{c}34 \\
(17.7)\end{array}$ & $\begin{array}{c}192 \\
(100)\end{array}$ \\
\hline $\begin{array}{l}\text { 하위 } \\
\text { 범주 }\end{array}$ & \multicolumn{14}{|c|}{ 자기표현 및 수용 } \\
\hline $\begin{array}{c}\text { 세부 } \\
\text { 활동명 }\end{array}$ & \multicolumn{2}{|c|}{$\begin{array}{l}\text { 색으로 } \\
\text { 감정 표현 } \\
\text { 하기 }\end{array}$} & \multicolumn{2}{|c|}{$\begin{array}{c}\text { 다양한 } \\
\text { 감정 표현 } \\
\text { 하기 }\end{array}$} & \multicolumn{2}{|c|}{$\begin{array}{c}\text { 부정적 감정 } \\
\text { 표현하기 }\end{array}$} & \multicolumn{2}{|c|}{$\begin{array}{l}\text { 나의 손 } \\
\text { 본뜨기 }\end{array}$} & \multicolumn{2}{|c|}{$\begin{array}{l}\text { 은유적 } \\
\text { 초상화 } \\
\text { 그리기 }\end{array}$} & \multicolumn{2}{|c|}{$\begin{array}{c}\text { 나의 감정 } \\
\text { 캐릭터 } \\
\text { 만들기 }\end{array}$} & $\begin{array}{c}\text { 기타 } \\
\text { 자기 표현 } \\
\text { 활동 }\end{array}$ & 합계 \\
\hline $\begin{array}{c}n \\
(\%)\end{array}$ & \multicolumn{2}{|c|}{$\begin{array}{c}10 \\
(5.7)\end{array}$} & \multicolumn{2}{|c|}{$\begin{array}{c}41 \\
(23.6)\end{array}$} & \multicolumn{2}{|c|}{$\begin{array}{c}46 \\
(26.4)\end{array}$} & \multicolumn{2}{|c|}{$\begin{array}{c}13 \\
(7.5)\end{array}$} & \multicolumn{2}{|c|}{$\begin{array}{c}8 \\
(4.6)\end{array}$} & \multicolumn{2}{|c|}{$\begin{array}{c}5 \\
(2.9)\end{array}$} & $\begin{array}{c}51 \\
(29.3)\end{array}$ & $\begin{array}{l}174 \\
(100)\end{array}$ \\
\hline
\end{tabular}




\subsection{3 타인 수용}

타인 수용에서 타인 관계 이해 및 수용 $(73.8 \%)$ 활동이 가족관계 이해 및 수용 $(26.2 \%)$ 보다 많은 것으로 나타났다. 타인 수용의 하위 범주의 세부 활동에 대한 빈도를 분석한 결과 먼저 가족관계 이해 및 수용에서는 동물 가족화 $(30.9 \%)$ 와 가족 모습 그리기(29.1\%)가 가장 많이 활용되었으며, 가족 소개하기(18.2\%), 가족에게 선물하기(14.5\%) 순으로 나타났다([표 6] 참조). 친구 신체 본뜨기(15.5\%)가 가장 많이 활용되었으며 그림으로 대화하기(13.5\%), 학교생활화 그리기(12.3\%), 친구에게 편지나 선물하기(12.3\%), 친구의 장점 찾기(11.6\%), 소중한 사람 그리기(11.0\%), 음식 만들기 $(9.7 \%)$ 순으로 나타났다.

[표 6] 타인 수용의 하위 범주의 세부 활동 빈도분석

[Table 6] Frequency Analysis of Activities by Subcategory of Other-acceptance

\begin{tabular}{|c|c|c|c|c|c|c|c|c|c|c|c|c|c|c|c|c|}
\hline $\begin{array}{l}\text { 하위 } \\
\text { 범주 }\end{array}$ & \multicolumn{6}{|c|}{ 가족관계 이해 및 수용 } & \multicolumn{10}{|c|}{ 타인관계 이해 및 수용 } \\
\hline $\begin{array}{c}\text { 세부 } \\
\text { 활 } \\
\text { 동명 }\end{array}$ & $\begin{array}{c}\text { 동물 } \\
\text { 가족 } \\
\text { 화 }\end{array}$ & $\begin{array}{c}\text { 물고 } \\
\text { 기 } \\
\text { 가족 } \\
\text { 화 }\end{array}$ & $\begin{array}{l}\text { 가족 } \\
\text { 소개 } \\
\text { 하기 }\end{array}$ & $\begin{array}{c}\text { 가족 } \\
\text { 모습 } \\
\text { 그리기 }\end{array}$ & $\begin{array}{l}\text { 가족 } \\
\text { 에 게 } \\
\text { 선물 } \\
\text { 하기 }\end{array}$ & 합계 & $\begin{array}{c}\text { 친구의 } \\
\text { 장점 } \\
\text { 찾기 } \\
\text { (칭찬하 } \\
\text { 기) }\end{array}$ & $\begin{array}{l}\text { 친구에 } \\
\quad \text { 게 } \\
\text { 편지나 } \\
\text { 선물하 } \\
\text { 기 }\end{array}$ & $\begin{array}{c}\text { 친구 } \\
\text { 신체 } \\
\text { 본뜨 } \\
\text { 기 }\end{array}$ & \begin{tabular}{|c} 
다른 \\
사람에 \\
게 \\
선물하 \\
기
\end{tabular} & $\begin{array}{l}\text { 소중한 } \\
\text { 사람을 } \\
\text { 표현 } \\
\text { 하기 }\end{array}$ & $\begin{array}{c}\text { 학교 } \\
\text { 생활화 } \\
\text { 그리기 }\end{array}$ & $\begin{array}{c}\text { 그림으 } \\
\text { 로 } \\
\text { 대화하 } \\
\text { 기 }\end{array}$ & $\begin{array}{c}\text { 음식 } \\
\text { 만들 } \\
\text { 기 }\end{array}$ & 기타 & 합계 \\
\hline $\begin{array}{c}n \\
(\%)\end{array}$ & $\begin{array}{c}17 \\
(30.9)\end{array}$ & $\begin{array}{c}4 \\
(7.3)\end{array}$ & $\begin{array}{c}10 \\
(18.2)\end{array}$ & $\begin{array}{c}16 \\
(29.1)\end{array}$ & $\begin{array}{c}8 \\
(14.5)\end{array}$ & $\begin{array}{c}55 \\
(100)\end{array}$ & $\begin{array}{c}18 \\
(11.6)\end{array}$ & $\begin{array}{c}19 \\
(12.3)\end{array}$ & $\begin{array}{c}24 \\
(15.5)\end{array}$ & $\begin{array}{c}10 \\
(6.5)\end{array}$ & $\begin{array}{c}17 \\
(11.0)\end{array}$ & $\begin{array}{c}19 \\
(12.3)\end{array}$ & $\begin{array}{c}21 \\
(13.5)\end{array}$ & $\begin{array}{c}15 \\
(9.7)\end{array}$ & $\begin{array}{c}12 \\
(7.7)\end{array}$ & $\begin{array}{c}155 \\
(100)\end{array}$ \\
\hline
\end{tabular}

\subsection{4 유능감 및 성취감}

유능감 및 성취감의 하위 범주에서 성취감(54.1\%)이 협동 및 문제 해결(45.9\%) 관련 활동보다 많았다([표 7] 참조). 협동 및 문제 해결 범주에서는 협동화 그리기 $(36.5 \%)$ 가 가장 많았고, 협동하여 만들기(23.5\%), 분할 조각 그림 그리기(10.6\%), 우리 마을 만들기(10.6\%), 만화 이어 그리기(8.2\%), 돌려가며 그리기(5.9\%) 순으로 나타났다. 성취감에서는 미래 모습 표현하기(40\%)와 미래의 나의 나무 만들기(26\%)가 많이 활용되고 있었으며 미래를 위해 계획 세우기(11\%), 나의 씨앗(5\%) 순으로 나타났다.

[표 7] 유능감 및 성취감의 하위 범주의 세부 활동 빈도분석

[Table 7] Frequency Analysis of Activities by Subcategory of Competence and Sense of Achievement

\begin{tabular}{|c|c|c|c|c|c|c|c|c|}
\hline $\begin{array}{l}\text { 하위 } \\
\text { ㅂㅓㄸㅈㅜ }\end{array}$ & \multicolumn{8}{|c|}{ 협동 및 문제해결 } \\
\hline $\begin{array}{c}\text { 세부 } \\
\text { 활 동명 }\end{array}$ & $\begin{array}{c}\text { 분할조각 } \\
\text { 그림 } \\
\text { 그리기 }\end{array}$ & $\begin{array}{l}\text { 협동화 } \\
\text { 그리기 }\end{array}$ & $\begin{array}{c}\text { 돌려가며 } \\
\text { 그리기 }\end{array}$ & $\begin{array}{c}\text { 만화 이어 } \\
\text { 그리기 }\end{array}$ & $\begin{array}{c}\text { 우리 마을 } \\
\text { 만들기 }\end{array}$ & $\begin{array}{l}\text { 협동하여 } \\
\text { 만들기 }\end{array}$ & $\begin{array}{l}\text { 역할극 } \\
\text { 하기 }\end{array}$ & 합계 \\
\hline $\begin{array}{c}n \\
(\%)\end{array}$ & $\begin{array}{c}9 \\
(10.6)\end{array}$ & $\begin{array}{c}31 \\
(36.5) \\
\end{array}$ & $\begin{array}{c}5 \\
(5.9) \\
\end{array}$ & $\begin{array}{c}7 \\
(8.2) \\
\end{array}$ & $\begin{array}{c}9 \\
(10.6)\end{array}$ & $\begin{array}{c}20 \\
(23.5)\end{array}$ & $\begin{array}{c}4 \\
(4.7) \\
\end{array}$ & $\begin{array}{c}85 \\
(100) \\
\end{array}$ \\
\hline $\begin{array}{l}\text { 하위 } \\
\text { 범주 }\end{array}$ & \multicolumn{8}{|c|}{ 성취감 } \\
\hline 세부 & 미래 모습 & 미래 & 위해 계획 & 미래의 & ㅏㅏㅇㅢ 나무 & 나의 & 기타 성취감 & 합계 \\
\hline
\end{tabular}




\begin{tabular}{|c|c|c|c|c|c|c|}
\hline 활 동명 & 표현하기 & 세우기 & 만들기 & 씨앗 & 활동 & \\
\hline$n$ & 40 & 11 & 26 & 5 & 18 & 100 \\
$(\%)$ & $(40.0)$ & $(11.0)$ & $(26.0)$ & $(5.0)$ & $(18.0)$ & $(100)$ \\
\hline
\end{tabular}

\subsection{5 마무리}

마무리 영역의 하위 범주에서는 피드백(60.3\%)을 자기평가(39.7\%)보다 더 많이 하는 것으로 나타났다([표 8] 참조).

[표 8] 마무리의 하위 범주의 세부 활동 빈도분석

[Table 8] Activities by Subcategory of Relationship Formation

\begin{tabular}{|c|c|c|c|c|c|c|c|}
\hline $\begin{array}{c}\text { 하위 } \\
\text { 범주 }\end{array}$ & \multicolumn{3}{|c|}{ 피드백 } & \multicolumn{3}{c|}{ 자기평가 } \\
\hline $\begin{array}{c}\text { 세부 } \\
\text { 활 동명 }\end{array}$ & $\begin{array}{c}\text { 친구에게 } \\
\text { 해주고 } \\
\text { 싶은 말 }\end{array}$ & $\begin{array}{c}\text { 작품 } \\
\text { 전시회 }\end{array}$ & $\begin{array}{c}\text { 종결 } \\
\text { 파티 }\end{array}$ & 합계 & $\begin{array}{c}\text { 나에 게 } \\
\text { 주는 상장 }\end{array}$ & $\begin{array}{c}\text { 나에 게 } \\
\text { 편지나 선물하기 }\end{array}$ & 합계 \\
\hline$n$ & 11 & 17 & 19 & 47 & 17 & 14 & 31 \\
\hline$(\%)$ & $(23.4)$ & $(36.2)$ & $(40.4)$ & $(100.0)$ & $(54.8)$ & $(45.2)$ & $(100.0)$ \\
\hline
\end{tabular}

마무리의 하위 범주의 세부 활동 빈도 분석 결과 피드백 하위 범주에서는 종결 파티(40.4\%), 작품전시회(36.2\%), 친구에게 해주고 싶은 말(23.4\%)의 순으로 나타났다. 분석 대상 논문을 살펴보면 종결 파티와 작품 전시회를 같이 하거나 작품 전시회와 서로에게 하고 싶은 말을 전하는 활동을 같은 회기 내에 함께 하는 경우가 많이 있었다. 자기평가 하위 범주에서는 나에게 주는 상장(54.8\%), 나에게 편지나 선물하기(45.2\%) 순으로 나타났다. 두 활동 모두 비슷한 비율로 이루어지고 있으며 자기 자신에 대한 스스로 평가는 나에게 주는 상장이나 나에게 편지나 선물을 주는 활동을 통해 스스로를 격려하고 칭찬하면서 모든 회기를 마무리할 수 있도록 구성되고 있음을 알 수 있다.

\section{4. 논의}

이 연구는 초등학생의 자아존중감 향상을 위한 집단미술치료 프로그램이 주로 어떤 활동들로 이루어져 있는지와 그 활동들의 내용을 알아보고 전체적인 프로그램의 구성을 체계적으로 분석하고자 하였다. 이 연구를 통해 나타난 주요한 결과를 논의하면 다음과 같다.

첫째, 분석 대상 논문의 프로그램을 구성요소별 빈도 분석 결과 자기 수용이 가장 높은 비중을 차지하였고 타인 수용, 유능감 및 성취감, 관계 형성, 마무리 순으로 나타났다. 자아존중감은 크게 자신이 사랑받고 있고 가치 있다는 생각과 자신이 유능하다는 생각으로 구성된다. 분석 대상이 되었던 프로그램들은 이 중에서도 자신이 사랑받고 가치 있다는 생각이 자아존중감에서 더 중요한 요소로 간주되고 있음을 알 수 있다. 이는 자아존중감과 자기수용이 깊은 관련성이 있으며[12] 자아존중감의 다면구조에 자기수용이 중요한 요인이라고 밝힌 것[13]과도 일치하는 결과이다. 심지어는 자아존중감을 대신해 자기수용(self-acceptance) 개념 사용을 제안한 연구자도 있었다[14]. 
왜냐하면 자기수용은 자신의 장점 이외에도 자신이 생각하는 단점까지도 있는 그대로 받아들이는 것을 의미하므로, 자기수용을 한 사람은 타인의 비판, 부정적인 사건 등을 경험해도 자신의 가치감에 상처를 입지 않기 때문이다. 다음으로, 타인 수용이 두 번째로 많은 빈도를 차지하였는데, 이는 타인으로부터의 긍정적인 존중은 자아존중감 변화의 입구와 같다고 지적한 것에서 그 이유를 찾을 수 있다[15]. 즉 자신에 대한 존중과 수용도 타인으로부터의 존재에 대한 인정과 존중이라는 단단한 바탕이 있을 때 가능한 것이다. 왜냐하면 아동들이 자신에 대한 관점을 형성하는 것은 중요한 타인이 거울이 되어 어떤 반응을 보이고 이들과 어떤 관계를 맺는지에 따라 형성되기 때문이다[16]. 특히 아동들에게 있어서 중요한 타인들과 어떤 관계를 맺고 있는지는 어떤 자아존중감을 가지게 될 것인지를 결정하는 주요 요인 중 하나이다. 이런 점에서 자아존중감 향상을 위한 집단을 진행하는 집단상담자들에게 무엇보다 민감성이라는 자질이 필요하다는 것을 알 수 있다. 세 번째로 많은 빈도를 차지한 것은 유능감과 성취감 영역이었는데, 자신이 중요하다고 생각하는 분야에서 잘 해낼 수 있을 것이라는 믿음은 자아존중감 형성의 중요한 축이지만 자아존중감 프로그램을 구성한 연구자들이 자아수용이나 타인 수용에 비해 비중을 크지 않게 인식하고 있음을 알 수 있다. 다만 이런 결과가 자아존중감 향상을 위한 집단미술치료 프로그램에서만 이런 비중을 가지고 있는 것인지 다른 형태의 집단 프로그램에서도 그런 것인지를 밝히는 연구가 필요할 것이다.

둘째, 각 프로그램의 하위 영역 활동에 대한 분석 결과를 살펴보면 다음과 같다. 우선 자기수용을 위한 자기 인식 및 이해 하위 범주에서는 '나의 장점과 단점 찾기', '나를 광고하기', '가면 만들기' 등의 활동이 많이 활용되었다. 이처럼 많이 활용된 활동들은 자신의 강점을 인식하고 그것을 강화하는 활동들이 가장 많이 선택되고 있음을 알 수 있다. 또한 자기표현 및 수용 하위 범주에서는 '부정적 감정 표현하기'와 '다양한 감정 표현하기, 등 감정을 표현하는 활동들이 많이 활용되었다. 이러한 활동의 빈도가 가장 높은 것은 자신의 강점이나 욕구를 인식하고 이해하는 것뿐 아니라 자신이 어떤 감정을 느끼고 있으며 그 감정은 왜 생기는지에 대한 이해를 하는 것이 중요하기 때문이다. 또한 이런 부정적인 감정을 미술 작업을 통해 표현하고 집단원들과 나누면서 공감받고 수용될 때 자아존중감이 높아지기 때문이다.

다음으로 타인 수용의 가족관계 이해 및 수용 하위 범주에서는 '가족 모습 그리기'와 '가족 동물화 그리기' 활동이 많이 활용되었다. 아동들에게는 가족의 모습을 있는 그대로 그리는 방법도 많이 활용되나 동물이나 물고기 등의 상징적인 작업을 많이 사용하고 있음을 알 수 있다. 그리고 타인 관계 이해 및 수용 하위 범주에서는 '신체 본뜨기', '그림으로 대화하기', ‘친구에게 편지나 선물하기', '학교생활화 그리기' 활동이 가장 많이 활용되었다. 이 하위 범주에서는 특히 친구와의 관계를 탐색할 수 있고 긍정적인 관계를 만들어 갈 수 있도록 하는 활동들이 많이 선택되고 있었다. 이는 아동기에는 또래 집단에 소속되기를 원하고, 친구와의 관계를 중요시 여기며, 또래 관계 안에서의 인정과 수용을 바탕으로 심리적 안정감이 생기며 자아존중감도 키워질 수 있는 활동들이 사용되고 있음을 알 수 있다.

그다음 순위는 유능감 및 성취감 영역이며 하위 범주는 협동 및 문제 해결과 성취감으로 나뉘었다. '협동화 그리기', '협동화 만들기' 등 협동을 통해 문제를 해결하는 활동들이 많이 활용되었으며, 미래 모습을 표현하거나 미래의 소망이나 희망을 보여주는 나무 만들기 활동을 통해 성취감을 고취시키는 활동들이 많았다. 이는 자아존중감이 자신의 욕구에 대한 성취의 비율로 표현될 수 있기 때문에 성취감을 느낄 수 있는 
활동들로 구성되었음을 보여주고 있다. 다만 자아존중감이 외적인 성취에만 바탕을 둔 것은 아니기 때문에 또래들과의 협동이나 문제 해결 경험을 확대할 수 있는 다양한 활동들이 개발될 필요가 있을 것이다.

셋째, 초등학교 자아존중감 향상을 위한 집단미술치료 프로그램에서 가장 많이 활용되는 세부 활동은 ‘부정적 감정 표현하기’(46회), ‘다양한 감정 표현하기’(41회), ‘미래 모습 표현하기'(40회), ‘나의 장점과 단점 찾기'(31회), ‘협동화 그리기'(31회) 이었다. 이는 아동의 사회성 향상 미술치료 프로그램 실태 분석[17]에서 따르면 초기에는 물감 활동이 가장 많았으며 중기에는 감정 관련 자유화 활동이, 종료 단계에서는 협동 작업 활동이 많다고 하여 이 연구 결과와 비슷한 부분들이 있었다. 이러한 활동들은 아동·청소년의 사회·정서 발달 프로그램 연구의 메타분석[18]에 따르면, 친사회적 행동과 태도를 익히며 정서조절을 통하여 친사회적 기술과 행동을 습득하여 자아존중감을 높이는 데 효과적이라고 하였다. 또, 초등학생을 대상으로 한 집단미술치료의 연구동향 분석[19]에서 단일 활동으로 별칭 짓기, 자유연상기법의 난화, 점토 작업, 가면 만들기, 협동화, 신체 본뜨기, 감정 표현하기, 명함 그리기, 희망 활동, 장점 찾기, 신문지 놀이, 만다라, 콜라주 활동이 높은 비중을 차지하고 있다는 것 과도 비슷하다. 이는 이 연구 결과의 세부 활동의 빈도수가 높은 활동들이 초등학생의 자아존중감 향상에 효과가 있으므로 추후 집단미술치료 프로그램 활동을 개발하거나 연구, 적용할 때 체계적인 자료로 활용될 수 있을 것으로 보인다.

이상의 논의를 통해 초등학생의 자아존중감 향상을 위한 집단미술치료 프로그램의 활동 내용 분석에 대한 연구의 교육적 의미를 찾아보면 다음과 같다. 첫째, 초등학생의 자아존중감 향상을 위한 집단미술치료 프로그램의 연도별 실시 현황과 형식적 특성을 살펴봄으로써 앞으로 집단미술치료 프로그램 개발 시 학술적 기초 자료의 근거를 제공하였다. 둘째, 초등학생의 자아존중감 향상을 위한 집단미술치료 프로그램의 활동 내용을 분석하여 어떤 활동으로 구성되어 있으며 어떤 내용이 주로 활용되고 있는지 구체적으로 제시함으로써 앞으로 보다 체계적으로 집단미술치료 프로그램의 세부 활동을 구성할 수 있는 근거를 마련할 수 있을 것으로 기대한다.

\section{References}

[1] S. Harter, Developmental perspectives on the self-esteem, Handbook of Child Psychology, New York: John Wiley, (1983), pp.275-385

[2] M. H. Park, M. J. Kim, Effects of elementary students' peer communication and self-esteem on adjustment to school life, The Korean Journal for Applied Developmental Psychology, (2015), Vol.4, No.1, pp.1-19.

[3] M. H. Kernis, Self-esteem Issues and Answers: A sourcebook of current perspectives, (1st Edition), New York, Psychology Press, (2013)

[4] H. J. Song, (A) meta-analysis on related variables to self-esteem, Yeonsei University, Master's thesis, (2005)

[5] U. Orth, R. W. Robins, The Development of self-esteem, Current Directions in Psychological Science, (2014), Vol.23, No.5, pp.381-387, DOI: 10.1177/0963721414547414

[6] S. J. Lee, I. J. Chung, A meta-analysis of self-esteem enhancement programs for children, Health and Social Welfare Review, (2018), Vol.38, No.3, pp.45-74, DOI: https://doi.org/10.15709/hswr.2018.38.3.45

[7] K. K. Kim, S. I. Lim, I. S. Park, Meta-analysis of self-esteem improvement program, The Journal of Educational Research, (2015), Vol.13, No.1, pp.21-42, UCI: G704-SER000010453.2015.13.1.008 
[8] J. Y. Park, Analysis of recent trends in the research of elementary school students' self-esteem: With a focus on dissertations since 2010, Daegu National University of Education, Master's thesis, (2019)

[9] J. Y. Lee, S. K. Nam, M. K. Lee, J. H. Lee, S. M. Lee, Rosenberg` self-esteem scale: Analysis of item-level validity, The Korean Journal of counseling and psychotherapy, (2009), Vol.21, No.1, pp.173-189, UCI: G704000523.2009.21.1.013

[10] K. D. Kim, O. J. Lee, Y. J. Kim, Social study research method, Seoul: Pakyoungsa, (2009)

[11] H. Y. Seon, M H. Lee, K. T. Park, S. H. Eom, Analysis of group counseling program on the career awareness of elementary schoolers, Asian Journal of Education, (2009), Vol.10, No.4, pp.1-30, DOI: 10.15753/aje.2009.10.4.001

[12] B. L. Thompson, J. A. Waltz, Mindfulness, Self-esteem, and unconditional self-acceptance, Journal of RationalEmotive \& Cognitive-Behavior Therapy, (2008), Vol.26, No.2, pp.119-126, DOI: https://doi.org/10.1007/s10942-0070059-0

[13] A. A. Norem-Hebeisen, A multidimensional construct of self-esteem, Journal of Educational Psychology, (1976), Vol.68, No.5, pp.559-565, DOI: https://doi.org/10.1037/0022-0663.68.5.559

[14] A. Ellis, How I learned to help clients feel better and get better. Psychotherapy, (1996), Vol.33, No.1, pp.149-151, DOI: https://doi.org/10.1037/0033-3204.33.1.149

[15] M. H. Kernis, Self-Esteem Issues and Answers: A Sourcebook of Current Perspectives, (1st Edition), New York: Psychology Press, (2013)

[16] W. S. Grolnick, K. L. Beiswenger, Facilitating Children's Self-esteem: The Role of Parents and Teachers, (Self-esteem: Issues and Answers: A Sourcebook of Current Perspectives), New York: Psychology Press, (2006), pp.230-237.

[17] S. Y. Lee, J. Y. Park, Analysis of Art therapy Program for Improving Children's Social Abilities, Journal of Clinical Art Psychotherapy Research, (2012), Vol.2, No.2, pp.47-64.

[18] H. S. Lee, I. S. Choi, S. I. Im, Meta-analysis of Social and Emotional Program for Children and Teenagers, The Korea Association of Child Care and Education, (2011), No.69, pp.233-255, UCI: G704-000724.2011..69.013

[19] S. D. Kim, Meta-analysis of the effects of group art therapy on elementary school students, Daegu National University of Education, Master's thesis, (2018) 